\title{
The Transformation of Budgetary Institution of Ministries/Agencies, The Perspective of Transaction Cost Analysis
}

\author{
Purwanto Dirsun ${ }^{1}$, Sudarsono Hardjosoekarto ${ }^{2}$, Roy Valiant Salomo ${ }^{3}$ \\ purwanto21@gmail.com¹, sudarsono72@ui.ac.id², roy.v09@ui.ac.id ${ }^{3}$ \\ Faculty of Social and Political Sciences, Universitas Indonesia ${ }^{1}$, Faculty of Social and Political Sciences, \\ Universitas Indonesia ${ }^{2}$, Faculty of Social and Political Sciences, Universitas Indonesia ${ }^{3}$
}

\begin{abstract}
As the Indonesian socio-political landscape has changed since 1998, budgetary institutional reform is necessary to strengthen the link between planning and budgeting. This paper aims to answer the question of how the planning and budgeting institution should be transformed, based on transaction costs analysis. Soft Systems Methodologybased Action Research was applied to explore five alternatives for planning and budgeting institutions. The integration of planning and financial institution is recommended supposing that bounded rationality, opportunism, asymmetric information, and uncertainty in planning and budgeting is high.
\end{abstract}

Keywords: planning and budgetary institution, transaction costs analysis, institutional transformation, soft systems methodology

\section{Introduction}

Each country has a different planning and budgeting system, mainly depending on ideology, political and government system, natural resource availability, and human resource capability [1]. In developed countries, the function of preparing long-term, mid-term, or annual plans is distributed to several organizations or managed by technical ministries rather than centralized in one organization. However, in developing countries, the function is centered on a committee or ministries/agencies [1]. In its development, as a result of the economic crisis or the transition to a market-oriented country, several countries such as Nigeria, Liberia, South Korea, and India changed their planning and budgeting system and institution [2] [3] [4] [5]. Despite their importance from the perspective of public administration, the institution and coordination system between planning and budgeting functions are under-studied and poorly understood [6]. This research objective is to answer the question of how planning and budgeting institution should be transformed, from the perspective of transaction cost analysis

The transformation of a budgetary institution in Indonesia

Political reform occurring in 1998 has allowed institutional transformation in Indonesia, including the planning and budgeting institution, i.e the changes from input-oriented to outcome-oriented budgeting, from annual to medium-term expenditure framework, and from dual budgeting to unified budgeting. This reform aims to accomplish a Well Performing Public 
Expenditure Management (PEM) [7] by which the aggregate fiscal discipline, the allocative efficiency, and operational efficiency could be attained.

Based on the 2016 Public Expenditure and Financial Accountability (PEFA) assessment [8], of 31 indicators assessed, Indonesia obtains: (i) 3 indicators $(10 \%)$ with a score of $\mathrm{D} / \mathrm{D}+$, (ii) 11 indicators $(30 \%)$ with a score of $\mathrm{C} / \mathrm{C}+$, (iii) 8 indicators with a score of $\mathrm{B} / \mathrm{B}+$, and (iv) 9 indicators with a score of $\mathrm{A}$, with $\mathrm{D}$ as the lowest score and $\mathrm{A}$ as the highest score [9]. In relation to expenditure budgeting, the dimension with a score of $\mathrm{C}$ is "alignment of strategic plans and medium-term budget". It is because the number of ministries/agencies whose strategic plans are integrated with a medium-term budget is limited in Indonesia. Based on the assessment, Indonesia needs to continue to adjust its budgetary institutions (values, norms, regulations, structures or procedures). In relation to the perspective of transaction cost economics [10] [11], Law No 17 of 2003 is the beginning of the transformation of budgetary institutions in Indonesia.

Hallerberg [12] provides the definition of budgetary institutions as follows:

"Budgetary institutions are the formal and informal rules governing budgetary decisions of the executive and legislative branches of government."

Meanwhile, the IMF in [13] defines budget institutions as:

"the structures, rules, and procedures that govern the formulation, approval, and

execution of government budgets."

Then, how to adjust the structure and process of the planning and budgeting? How the budget allocation and performance targets for each ministry/agencies should be decided? To answer these questions, this study applied transaction cost economics (TCE) approach [14], [15] [16] referring to Williamson TCE [17], [18]. The TCE approach by Williamson focuses on discovering efficient governance (in the broad sense) of transactions/exchanges between the parties performing the transactions. The TCE approach is applied in this study since according to [19], budgeting is a transaction. It is assumed that a budgeter shall minimize transaction costs, namely costs incurred to obtain information regarding the needs and capabilities of ministries/agencies in generating outputs/outcomes as well as monitoring and maintaining agreements [19].

\section{Budgetary Institutions}

The existence of the ministry of planning and the ministry of finance as planning and budgeting institutions in Indonesia is rather unique [20] [21] [22]. In developed countries, the ministry of finance has a strong role, hence a specific institution to manage national planning is non-existence. However, the role of planning institutions in Indonesia is not as strong as that of other developing countries such as Bangladesh, Myanmar, several countries in Africa, and socialist countries [20]. In these countries, the allocation of development budgets is generally managed by planning institutions while financial institutions manage financial affairs other than budgeting [20]. Meanwhile, several countries previously had separate planning and budgeting institutions, eventually merge them into one institution (vertical integration), such as South Korea and Brazil [20]. Since 2014, the India Central Planning Commission in India has been removed and replaced by the National Institution for Transforming India Aayog (NITI Aayog) with a role as a think-tank institution instead of allocating budgets [23].

One of the factors suspected as the cause of the uniqueness in Indonesia is the absence of a "bridge" between Law No 17 of 2003 on State Finance and Law No 25 of 2004 on the National Development Planning System. In a bid to connect them, the Government has issued the 
Government Regulation (PP) No 17 of 2017 on Synchronization of the National Development Planning and Budgeting Process. However, the PP has not been able to eliminate the uniqueness of planning and budgeting institutions in Indonesia since both institutions have to jointly allocate the budget ceiling for ministries/agencies [20]. It has the potential to cause transaction cost inefficiencies since a similar function is carried out by more than one institution.

\section{Transaction Cost Analysis in the Planning and Budgeting Institutions}

In the framework of transaction cost economics (TCE) theory by Williamson [24], [25], an organization has three options to obtain input in order to produce output, namely to buy from input markets (without contracts), to make (vertical integration/hierarchy), or the combination of both (hybrid/bilateral contract agreements). According to the perspective of TCE, two separate planning and budgeting institutions equally requiring information regarding budget and output have three main options:

a. To make their own planning and budgeting processes (each choosing hierarchy). The two institutions shall compete to produce more or less similar output. It means that there shall be duplication and inefficiency in the utilization of public funds. To avoid inefficiency caused by the competition, both institutions may be merged (vertical integration) to a new form of hierarchy. According to [15] vertical integration is an option to overcome significantly high behavioral and environmental uncertainty. According to [14], several forms of the hierarchy have the ability to mitigate bounded rationality particularly caused by limited processing capacity, cognitive economizing, and cognitive biases. Meanwhile, according to [26], several forms of the hierarchy have the potential to mitigate uncertainty due to interpretation.

b. To exchange information on budget availability, program/activity/output costs, and output/outcome targets to jointly allocating a budget of ministries/agencies (hybrid) afterward. According to [15], it is an example of a hybrid in the form a formal contractualbased relationship or informal trust-based coordination.

c. To buy information and produce a different output (specialization) yet compatible. In this option, the planning institution may create a plan that aggregately requires equal funds to the resource envelope informed by the budgeting institution. The plan does not violate fiscal discipline and sustainability. On the contrary, the budgeting institution may prepare budget allocation of ministries to produce output/outcome based on the information about prioritized output/outcome delivered by the planning institution.

Each option has risks and benefits, and the option to be chosen is the one with the best costeffective. The option shall be determined by the attributes of a transaction, namely asset specificity, uncertainty, and frequency [27]. The existence of uncertainty, along with asymmetric information, bounded rationality, and opportunism in planning and budgeting process and institution needs to be mitigated to minimize transaction costs.

As far as the authors know, TCE that has developed so far is utilized to analyze the exchange or transaction between one company and another (i.e. contracts and franchises) or between the government and the private sector (i.e. public-private partnership or contracting out), all of which are hybrid. Further study is necessary to analyze how these attributes play a role in exchanges/transactions among fellow public/government agencies, in this regard the planning institution, budgeting institution, and technical ministry that in preparing plans and budgets for programs/activities/output-outcome have the authority with the potential to be overlapping and identical. 


\section{Soft Systems Methodology for Defining Budgeting Institutions}

Checkland and Poulter [28] explain that SSM is significantly proper to be utilized as an alternative study model, namely a social study model at the level of a group or organization, or action research. SSM-based action research assumes that the problem faced is complex pluralist. It is in accordance with the character of research problems in the area of Human Activity Systems, where the cognitive process of the actors in the system becomes considerably important to discover the findings of the study. Uchiyama (2009) explains that action research facilitates an endless cycle of the process of "learning by doing". Checkland [29] emphasizes SSM in problematic situations rather than merely theories. However, the framework shall be conveyed from the beginning. Checkland and Poulter [28] even highlight the importance of "declaring framework in advance".

Most of the literature on action research defines it in the context of learning by doing primarily for problem-solving purposes [30]. According to O'Brien (1998), quoted in Hardjosoekarto [30], the problem-solving process with action research is distinguishable from the problem-solving process in the daily sense from its emphasis on scientific studies. It means that researchers in an action research study the problem to be solved in a systematic way and ensure that the intervention carried out is based on certain theoretical considerations.

According to [29], researchers have to state the theoretical framework (F) and method (M) applied to formulate and direct research interventions as well as create the impression of accumulated experience in those research interventions. In this study, the orientation is problemsolving, in which the action research begins with the formulation of theoretical framework $(\mathrm{F})$, the methodology for research interest (MR), real-world problematic situations $(\mathrm{P})$ and specific areas to be studied (A), as explained in Table 1.

Table 1. The framework of the Study of the Transformation of Budgetary Institutions The Perspective of Transaction Cost Analysis

\section{Information}

Theoretical Framework (F)

Theoretical construction of the characteristics of transaction costs [15] [14] [26] [31] is applied to discover the governance structure of budget allocations of ministries/agencies streamlining the transaction costs of Williamson's version.

\begin{tabular}{ll}
\hline $\begin{array}{l}\text { Methodology for research interest } \\
\text { (MR) }\end{array}$ & $\begin{array}{l}\text { Soft Systems Methodology-based Action Research with } \\
\text { enrichment }\end{array}$ \\
\hline $\begin{array}{l}\text { Real-world problematic situations } \\
\text { (P) }\end{array}$ & $\begin{array}{l}\text { The implementation of the performance-based budget in } \\
\text { ministries/agencies is considerably complex and problematic, } \\
\text { hence the need for a comprehensive by referring to a budget } \\
\text { allocation by the Ministry of National Development Planning } \\
\text { (Bappenas) and Directorate General of Budget (DJA) in } \\
\text { accordance with Presidential Regulation No 17 of 2017. }\end{array}$ \\
\hline $\begin{array}{l}\text { Methodology for problem-solving } \\
\text { (Mps) }\end{array}$ & \begin{tabular}{l} 
Soft Systems Methodology (SSM)-based action research \\
\hline A specific area to be studied (AA)
\end{tabular} \\
& $\begin{array}{l}\text { The perspective of transaction costs [15] [14] [26] [31] } \\
\text { regarding performance-based budget allocation of } \\
\text { ministries/agencies }\end{array}$
\end{tabular}


Checkland and Poulter [32] explain that the basic process of SSM is a learning cycle starting from finding problematic situations and determining actions to provide improvements to problems. The application of SSM includes 7 (seven) stages known as the SSM standard cycle as follows: 1) problem situation considered problematic; 2) problem situation expressed; 3) root definitions of relevant purposeful activity systems; 4) conceptual models of the systems (holons) named in the root definition; 5) comparison of models and real-world; 6) change: systematically desirable and culturally feasible; and 7) action to improve the problem situation.

In accordance with the Second Stage of SSM by Checkland [33], unstructured problems that are difficult to understand are mapped based on the applied theory and presented in a Rich Picture (Figure 1), resolving the problems into structured problems that are easily understood by observing the problems from various perspectives. This study develops several options of a system for allocating budget ceilings of ministries/agencies able to minimize transaction costs. Such a system, using the Soft Systems Methodology (SSM) method, shall meet at least three criteria (efficacy, efficiency, and effectiveness) as well as be culturally feasible and systematically desirable [30]. According to [28], three aspects to be considered in transforming or improving a system are structure, processes or procedures, and attitudes.

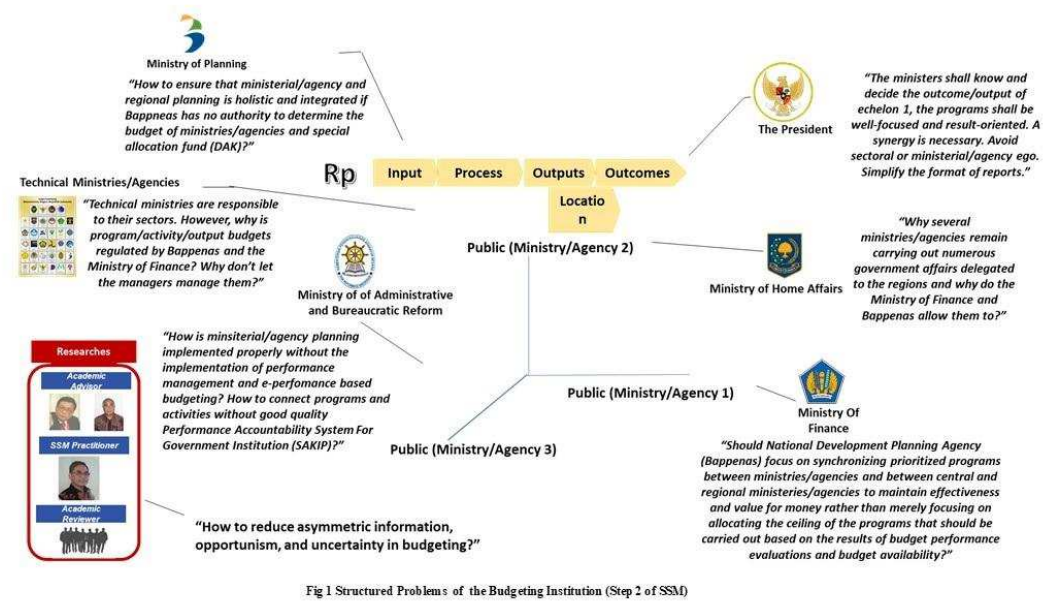

Figure 1

The aspect of governance structure focuses on who carries out the tasks and what responsibilities, while the aspect of the process focuses on how the implementation of the tasks 
and responsibilities [34]. Observed from the structure, the system of allocating budget ceiling of ministries/agencies is carried out jointly by Bappenas and the Ministry of Finance, as stipulated in PP No 17 of 2017 on Synchronization of National Development Budgeting Planning (SPPN). However, the definition of "jointly" in allocating the ceiling for certain performance achievements needs to be further elaborated [22] and [20].

In terms of the process, the budget ceiling is obviously allocated through a process involving at least Bappenas, the Ministry of Finance, and ministries/agencies. The question is how to increase efficiency, effectiveness, and value for money from the budget ceiling allocation process. In this study, these two aspects are improved through the approach of transaction cost analysis by Williamson [35] [36] [37]. The improvement also requires improvement in behavior and culture [11], two aspects undiscussed in this study. In the analysis of transaction costs, governance structure and process are the objects of interest. The main question of this study is how the structure and process of the exchange between budget allocation and performance expected are able to occur with more efficient socio-economic costs.

In accordance with the problems illustrated in Figure 1 and utilizing the perspective of transaction costs, this study selects 5 (five) relevant systems and then develops 5 (five) models of allocation of the budget ceiling of ministries/agencies. The five conceptual models are inspired by the perspectives of the officials and employees within the Ministry of Finance (MOF) and Bappenas obtained from an informal discussion, as allowed by the SSM. The five models are also inspired by suggestions from parties other than these two ministries, such as observers and researchers from academics, international institutions, as well as from the experiences of several other countries.

\section{Comparison of models and real world}

While comparing the conceptual models with the real world, the five models certainly have their respective supporters. However, the parties interviewed or involved in the discussion tend to focus more on comparing the process of planning and budgeting between the current application process and the offered institutions in this study, namely the process considered more capable of minimizing transaction costs caused by asymmetric information, bounded rationality, opportunism, and uncertainty. The following paragraphs describe briefly the five alternatives of budgetary institutions developed further after the comparison of the models and the real world.

The 1st alternative is formed by utilizing the available regulations, i.e PP No 17 of 2017 on Synchronizing of National Development Budgeting Planning. As reminded in [20], the term "jointly" in several articles requires further study, regarding whether it is compulsory or how it is supposed to be implemented. For example, Article 9 paragraph 5 of PP 17/2017 states:

The Minister of Finance and the Minister of National Development Planning jointly compile

budget availability by considering the Macro-Economic Framework and the Principles of

Fiscal Policy, or

According to several parties in the MOF, this article is not in compliance with Law No 17 of 2003 on State Finance assigning fiscal authority to the MOF. The PP No 17 of 2017 doesn't explain to what extent 'jointly' is carried out and how decisions are taken should there are differences in opinion.

The 2nd alternative is formed based on past experiences when Bappenas had centralized authority in planning the development executed by ministries/agencies and local governments. As reported in [38], during the New Order, Bappenas was responsible for formulating National Development plans, the draft of State Budget (jointly with the Ministry of 
Finance), credit and investment policies (jointly with the relevant institutions), policies on credit acceptance and utilization, and foreign aid. In addition, Bappenas had the functions to observe the preparation and development of the implementation of the plans, synchronize programs and projects, and evaluate and adjust the implementation of the plans [38]. However, the budgeting process in the second alternative has been adjusted to the present context, where political and financial decentralization has been strongly applied. The Secretary of the Cabinet, Pramono Anung, dismissed the assumption that Bappenas shall regain the authority it once had during the New Order.

"It will not transform into what it was during the New Order. However, since the House of Representatives (DPR) currently has no authority to discuss budget to unit three, the planning entirely becomes the authority of Bappenas." [38].

Observed from the perspective of TCA, the statements above illustrate the differences in perceptions regarding the idealized governance structure and budgeting process. The second model attempts to obtain a solution by utilizing the perspective of TCA.

The 3rd is formed based on experience in several years since the 2008/2009 economic crisis, when the global economy experienced stagnation or significantly low economic growth, negatively causing the uncertainty of state revenues, particularly tax revenues, and the ability to finance budget deficits. On the other hand, by having better data on budget realization through the State Treasury and Budget System (SPAN), the MOF was able to monitor and evaluate budget execution and disbursement better to produce an analysis of the efficiency and effectiveness of the programs/activities of ministries/agencies, serving as input for budget allocation in the following year. These two issues, namely uncertainty regarding tax revenues and the increasing demand for more efficient and effective budget utilization, have encouraged the MOF to assume its duties and responsibilities in accordance with Law No 17 of 2017, previously executed by Bappenas. The MOF is no longer merely allocate the recurrent expenditures such as in the past, but also allocate the overall expenditures of each ministry/agency. Similar strengthening of the responsibilities of the MOF has occurred in other countries facing uncertainty as new normality [39] [40] [6]. Observed from the perspective of TCA, the third alternative attempts to reduce uncertainty while empowering the asset specificity already owned by the Ministry of Finance.

The 4th is inspired by a practice in the United States [41], imitated by several other countries including the Philippines [42] [43]. In this model, there is no ministry managing planning nationally or centrally, while the MOF focuses more on the management of state fiscal sustainability and health. The planning function and the budgeting function carried out by Bappenas and the MOF respectively are integrated into one ministry whose main task is to ensure that the planning of ministries/agencies is in line with the president's policy, without having to be authoritarian, by providing guidance and counseling to prepare plans and implement them efficiently, effectively and optimally [44] [45] [46]. Such planning and budgeting agency also assists ministries/agencies in solving problems in the implementation phase (debottlenecking) [47]. Observed from the perspective of TCA, this 4th alternative is to unify asset specificity from planning institutions and budgeting institutions.

The 5th is inspired by the experience of South Korea, which eventually (re)uniting planning and budgeting units into the Ministry of Strategy and Finance in 2008, previously known as the Ministry of Economy and Finance in the period 1994-1998. Prior to 2008, there was a separation between the two functions into the Ministry of Finance and the Ministry of Planning and Budget [48] [49] [50]. This fifth alternative has the potential to further optimize asset specificity of the 
two ministries while reducing the uncertainty arising from environmental and macroeconomic uncertainty.

From the perspective of transaction costs, the alternatives constituting the governance structure of hierarchy are the second and the third alternatives. The first alternative is a hybrid of a coordinating nature, while the fourth and the fifth are hybrid of the organizational mergers.

\section{Conclusion}

This paper illustrates the process of planning and budgeting institutional reform. The sources of transaction costs in planning and budgeting, namely uncertainty, opportunism, bounded rationality, and asymmetric information [14] [26] [15] [16] are possible to be mitigated by the change in the institutional process and structure. SSM can be used to explore various possible budgetary institutions and processes minimizing transaction costs. SSM assists stakeholders in providing input to each other related to various models, even those they previously dislike due to the assumption that a certain model is detrimental to their position.

\section{Acknowledgment}

The authors express their gratitude to Irfan Ridwan Maksum, Ferdinand D Saragih, Deddy Bratakusumah, Machfuz Sidik, and Martani Huseini for their valuable input. All responsibilities are borne by the authors.

\section{Disclaimer}

The opinions and findings of this study do not represent the institution in which the authors are affiliated.

\section{References}

[1] R. Allen, "Planning and Budgeting in Developing Countries - 'Shrinking the P,'" IMF Public Finance Management-Blog, 2011. [Online]. Available: https://blogpfm.imf.org/pfmblog/2011/01/planning-and-budgeting-in-developing-countriesshrinking-the-p-.html. [Accessed: 03-Apr-2019].

[2] A. Singh, "Coordinating the Planning and Budgeting Functions of Government," IMF Public Finance Management-Blog, 2017. [Online]. Available: https://blogpfm.imf.org/pfmblog/2017/04/coordinating-the-planning-and-budgeting-functions-ofgovernment.html\#_ftn4. [Accessed: 03-Apr-2019].

[3] J. Kim, "The Role of Fiscal Institutions for the Sustained Economic Growth of Korea," in Planning and Budgeting in Korea and Selected Asian Countries, 2014, pp. 2-52.

[4] W. Gumede, "Comparative Country Long-Term Development Planning: Lessons for South Africa," no. July 2014.

[5] G. Turley and G. N. U. I. Galway, "Economic Transformation : From Central Planning to Market Economy," International Encyclopedia of Social \& Behavioral Sciences, vol. 6. Elsevier, pp. 73-79, 2015.

[6] P. Krause, S. Hadley, S. Mustapha, and B. Welham, "The Capabilities of Finance Ministries," London SE1 8NJ, 2016.

[7] The World Bank, PUBLIC EXPENDITURE MANAGEMENT HANDBOOK. Wahington D.C.: The World Bank, 1998. 
[8] PEFA Secretariat, PEFA Framework for assessing public financial management. Washington DC, USA: PEFA Secretariat, 2016.

[9] The World Bank, "Indonesia Public Expenditure and Financial Accountability (PEFA) Assessment Report 2017," 2018.

[10][D. C. North, Institutions, Transaction Cost and Economic Growth, vol. 25, no. 3. 1987.

[11] O. E. Williamson, "The New Institutional Economics: Take Stock, Looking Ahead," Journal of Economic Literature, vol. Vol. 38 No, no. September, pp. 596-613, 2000.

[12] J. de Haan, R. Jong-A-Pin, and J. O. Mierau, "Do budgetary institutions mitigate the common pool problem ? New empirical evidence for the EU," pp. 423-441, 2013.

[13] R. Hughes et al., "IMF Policy Paper: BUDGET INSTITUTIONS IN G-20 COUNTRIES : AN UPDATE," Washington DC, 2014.

[14] N. J. Foss and L. Weber, "Moving Opportunism to the Back Seat: Bounded Rationality, Costly Conflict, and Hierarchical Forms," Academy of Management Review, p. 42, 2014.

[15]R. Krishnan, I. Geyskens, and J.-B. E. M. Steenkamp, "The Effectiveness of Contractual and Trust-based Governance in Strategic Alliances under Behavioral and Environmental Uncertainty,” Strategic Management Journal, no. October, p. 22, 2015.

[16] I. Geyskens, J.-B. E. Steenkamp, and N. Kumar, "Make, buy, or ally: A transaction cost theory meta-analysis," Academy of Management Journal, vol. 49, no. 3, pp. 519-543, 2006.

[17] Oliver E. Williamson, "The Economics of Organization: The Transaction Cost Approach," The American Journal of Sociology, vol. 87, no. No. 3 (November 1981), p. 32, 1981.

[18] O. E. Williamson, "Transaction Cost Economics and Public Administration," Public Priority Setting: Rules and Costs. pp. 19-37, 1997.

[19]E. Patashnik, "The contractual nature of budgeting: A transaction cost perspective on the design of budgeting institutions," Policy Sciences, vol. 29, no. 3, pp. 189-212, 1996.

[20] K. A. Whimp and H. Purnomo, "PSI analysis on PP 172017 on planning and budgetingWorldbank." World Bank, 2017.

[21]J. R. Blöndal, D. Bergvall, I. Hawkesworth, and R. Deighton-smith, "Budgeting in Australia," OECD Journal of Budgeting - Volume 8-No. 2, vol. 8, no. 2, pp. 1-64, 2008.

[22] I. Hawkesworth, H. Choi, and J. R. Blondal, "Budgeting in Indonesia," OECD Journal on Budgeting, vol. 2, pp. 1-31, 2009.

[23] M. J. Ali and M. Rahaman, "Planning decentralization and changing paradigm of Indian planning process," International Planning Studies, no. 21 Feb, pp. 1-14, 2018.

[24]O. E. Williamson, "Public and private bureaucracies: a transaction cost economics prespective," Journal of Law, Economics \& Organisations, vol. 15, no. 1, pp. 306-342, 1999.

[25] O. E. Williamson, "Transaction cost economic: the natural progression," American Economic Review, vol. 100, no. June, pp. 673-690, 2010.

[26]L. Weber and K. Mayer, "Transaction Cost Economics And The Cognitive Perspective: Investigating The Sources and Governance of Interpretive Uncertainty," Academy of Management Review, vol. 39, no. 3, pp. 344-363, 2014.

[27]O. E. Williamson, "Transaction-Cost Economics: the Governance of Contractual Relations," Journal of Law and Economics, vol. 22, no. 2, pp. 233-261, 1979.

[28]P. Checkland and J. Poulter, Learning for Action: A Short Definitive Account of Soft Systems Methodology and its Use, for Practitioners, Teachers and Students. Chichester: John Wiley and Sons Ltd., 2006.

[29] P. B. Checkland and P. B. Checkland, "Science and the Systems Paradigm," pp. 259-268, 1991. 
[30] S. Hardjosoekarto, "Construction of Social Development Index as a Theoretical Research Practice in Action Research by Using Soft Systems Methodology," Systemic Practice and Action Research, vol. 25, no. 6, pp. 493-509, 2012.

[31]I. Geyskens, J.-B. E. M. Steenkamp, and N. Kumar, "Make, Buy, or Ally: A Transaction Cost Theory Meta-Analysis," Academy of Management Journal, vol. 49, no. 3, pp. 519543, Jun. 2006.

[32] P. Checkland and J. Poulter, "Soft Systems Methodology," in Systems Approaches to Managing Change, M. Reynolds and S.Holwell, Eds. The Open University 2010. Published in Association with Springer-Verlag London Limited, 2010, pp. 191-242.

[33]P. Checkland, "Systems Thinking and Soft Systems Methodology," in The Oxford Handbook of Management Information Systems: Critical Perspectives and New Directions, 1999 First., R. D. Galliers and W. L. Currie, Eds. Oxford University Press, 2019, p. 2019.

[34] Ó. Williamson, The New Institutional Economics: Take Stock, Looking Ahead., vol. 38. 2000.

[35] O. E. Williamson, "Why Law, Economics, and Organization?," Annual Review of Law and Social Science, vol. 1, no. 1, pp. 369-396, 2005.

[36]B. BAUDRY and V. CHASSAGNON, "The close relation between organization theory and Oliver Williamson's transaction cost economics: a theory of the firm perspective," Journal of Institutional Economics, vol. 6, no. 04, pp. 477-503, 2010.

[37] M. Mikami, "Methodological Divergence between Coase and Williamson in the History of Transaction Cost Economics," Economic Journal of Hokkaido University, vol. 40, pp. 41-57, 2011.

[38] Kompas.com, "Bappenas Ingin Dikembalikan Seperti Zaman Orde Baru_ - Kompas," ekonomi.kompas.com, 2015. [Online]. - Available: https:/ekonomi.kompas.com/read/2015/08/31/140737726/Bappenas.Ingin.Dikembalikan .Seperti.Zaman.Orde.Baru.

[39]R. Allen, Y. Hurcan, P. Murphy, and M. Queyranne, "The Evolving Functions and Organization of Finance Ministries," IMF Working Paper, vol. WP/15/232, no. November, 2015.

[40] Convergence Center for Policy Resolution, "Final Report - Convergence Building a Better Budget Process," 2018.

[41] D.-J. K. and M. R. Jón R. Blöndal, "Budgeting in the United States," OECD Journal on BUdgeting, vol. 3, no. No.2, pp. 7-53, 2003.

[42] J. R. Blöndal, "Budgeting in the Philippines," OECD Journal on Budgeting, vol. 2, pp. 122, 2010.

[43]Rep of the Philippines-Dept. of Budget and Management, "Philippine PerformanceInformed Budgeting System," in the 11th Annual OECD SBOM, Bangkok December 17. 2015, 2015, p. 19.

[44] Office of Management and Budget, "Budget Concepts and Budget Process.” p. 56, 2015.

[45] OMB, "Section 10-Overview of the Budget Process," 2017.

[46] US Government Accountability Office, "MANAGING FOR RESULTS, OMB Improved Implementation of Cross-Agency Priority Goals, But Could Be More Transparent About Measuring Progress, Report to Congressional Committees," 2016.

[47] OMB, "Guidance on Exhibit 300-Planning, Budgeting, Acquisition, and Management of IT Capital Assets," 2011.

[48] J. Choi, "HOW TO INTEGRATE PLANNING AND BUDGETING? Focusing on Korean experience," no. December. OECD, p. 13, 2015. 
[49] J. M. Kim, "Performance Budgeting in Korea," in 2017 OECD-Asian Senior Budget Officer Meeting, 14-15 December 2017, 2017, no. December.

[50] Ministry of Strategy and Finance, The Budget System of Korea. 2014. 